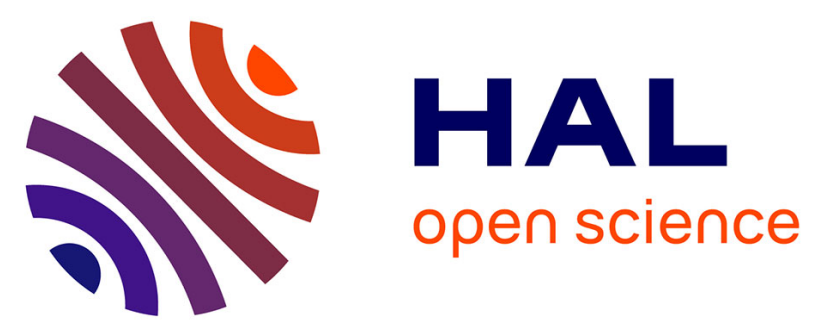

\title{
Phylogenetic analysis of the RNA-dependent RNA polymerase (RdRp) and a predicted structural protein (pSP) of the Chronic bee paralysis virus (CBPV) isolated from various geographic regions.
}

Philippe Blanchard, Frank Schurr, Violaine Olivier, Olivier Celle, Karina Antùnez, Tamàs Bakonyi, Hélène Berthoud, Eric Haubruge, Mariano Higes, Sylwia Kasprzak, et al.

\section{- To cite this version:}

Philippe Blanchard, Frank Schurr, Violaine Olivier, Olivier Celle, Karina Antùnez, et al.. Phylogenetic analysis of the RNA-dependent RNA polymerase (RdRp) and a predicted structural protein (pSP) of the Chronic bee paralysis virus (CBPV) isolated from various geographic regions.. Virus Research, 2009, 144 (1-2), pp.334-8. 10.1016/j.virusres.2009.04.025 . hal-00419893

HAL Id: hal-00419893

https://hal-anses.archives-ouvertes.fr/hal-00419893

Submitted on 25 Sep 2009

HAL is a multi-disciplinary open access archive for the deposit and dissemination of scientific research documents, whether they are published or not. The documents may come from teaching and research institutions in France or abroad, or from public or private research centers.
L'archive ouverte pluridisciplinaire HAL, est destinée au dépôt et à la diffusion de documents scientifiques de niveau recherche, publiés ou non, émanant des établissements d'enseignement et de recherche français ou étrangers, des laboratoires publics ou privés. 
1 PHYLOGENETIC ANALYSIS OF THE RNA-DEPENDENT RNA POLYMERASE (RdRp) AND A PREDICTED STRUCTURAL PROTEIN (pSP) OF THE CHRONIC BEE PARALYSIS VIRUS (CBPV) ISOLATED FROM VARIOUS GEOGRAPHIC REGIONS.

5

\section{Philippe Blanchard* ${ }^{1}$, Frank Schurr ${ }^{1}$, Violaine Olivier $^{1}$, Olivier Celle ${ }^{1}$,} Karina Antùnez ${ }^{2}$, Tamàs Bakonyi ${ }^{3}$, Hélène Berthoud ${ }^{4}$, Eric Haubruge ${ }^{5}$, Mariano Higes ${ }^{6}$, Sylwia Kasprzak ${ }^{7}$, Hemma Koeglberger ${ }^{8}$, Per Kryger $^{9}$, Richard Thiéry ${ }^{1}$, Magali Ribière ${ }^{1}$.

${ }^{1}$ Agence Française de Sécurité Sanitaire des Aliments (AFSSA), Les Templiers, Route des Chappes, BP 111, 06902 Sophia Antipolis, France.

2 Laboratorio de Microbiologia, Instituto de Investigaciones Biologicas Clemente Estable, Avenida Italia 3318, CP 11600 Montevideo, Uruguay.

${ }^{3}$ Department of Microbiology and Infectious Diseases, Faculty of Veterinary Science, Szent Istvàn University, H-1143 Budapest, Hungary.

${ }^{4}$ Agroscope Liebefeld-Posieux Research Station ALP, Mikrobiologie, Schwarzenburg Strasse 161, CH-3003 Bern, Switzerland.

${ }^{5}$ Faculté Universitaire des Sciences Agronomiques, Unité d'Entomologie fonctionnelle et évolutive, Passage des Déportés, B-5030 Gembloux, Belgium.

${ }^{6}$ Centro Apicola Regional, Direccion General de la Produccion Agropecuaria, Consejeria de Agricultura, Junta de Comunidades de Castilla-La Mancha, 19180 Marchamalo, Spain.

${ }^{7}$ National Veterinary Research Institute, Department of Parasitology and Invasive Diseases, Al. Partyzantow 57, 24-100 Pulawy, Poland.

${ }^{8}$ Institut für Bienenkunde, Spargelfeldstrasse 191, 1220 Wien, Austria.

${ }^{9}$ University of Aarhus, Faculty of Agricultural Sciences, Department of Integrated Pest Management, Forsogsvej 1, DK-4200 Slagelse, Denmark. 
$29{ }^{*}$ Corresponding author

30 Mailing address: Blanchard Philippe, AFSSA Sophia-Antipolis, Unité Pathologie de l'Abeille,

31 Les Templiers, BP 111, Fr - 06902 Sophia Antipolis

32 Telephone number: +33.492 .948 .769$

33 Fax number: +33.492 .943 .701$

34 e-mail: p.blanchard@afssa.fr 
37 Chronic bee paralysis virus (CBPV) is responsible for chronic paralysis, an infectious and

38 contagious disease of adult honey bees (Apis mellifera L.). The full-length nucleotide 39 sequences of the two major RNAs of CBPV have previously been characterized. The Orf3 of 40 RNA1 has shown significant similarities to the RNA-dependent RNA polymerase (RdRp) of 41 positive single-stranded RNA viruses, whereas the Orf3 of RNA2 encodes a putative 42 structural protein (pSP). In the present study, honey bees originating from 9 different 43 countries (Austria, Poland, Hungary, Spain, Belgium, Denmark, Switzerland, Uruguay and 44 France) were analysed for the presence of CBPV genome. The complete genomic nucleotide 45 sequence of the $\operatorname{RdRp}(1947 \mathrm{bp}$ ) and of the pSP (543bp) from 24 honey bee positive samples 46 was determined and the phylogenetic relationship among isolates was investigated. Four 47 distinct genotypes of CBPV were observed.

48

49 Keywords: Chronic bee paralysis virus (CBPV), RNA-dependent RNA polymerase, Predicted 50 structural protein, Phylogenetic analysis, Apis mellifera. 


\section{Short communication}

53

Chronic bee paralysis virus (CBPV) is the aetiological agent of an infectious and contagious disease of adult honey bees (Apis mellifera L.) known as Chronic paralysis (Ball \& Bailey, 1997). This pathology is known to induce significant losses in honey bee colonies (Allen \& Ball, 1996), characterized by clusters of trembling, flightless, crawling bees and by individual black, hairless bees standing at the hive entrance (Bailey et al., 1983; Ball \& Bailey, 1997). Although the complete sequences of the two major genomic RNAs of CBPV have recently been determined (Olivier et al., 2008), its taxonomic position is currently unassigned (Mayo et al., 2005). RNA1 (3674 nt) and RNA2 (2305 nt) are positive single-stranded RNAs that are capped but not polyadenylated. Although CBPV shares several characteristics with viruses of the Nodaviridae and Tombusviridae families, CBPV could be considered as the type species of a new family of positive single-stranded RNA viruses (Olivier et al., 2008).

The distribution of CBPV is worldwide (Allen \& Ball, 1996; Ribière et al., 2008). The prevalence of this virus has been investigated in various countries, such as Great Britain (Bailey et al., 1981), Poland (Topolska et al., 1995), France (Ribière et al., 2000; Tentcheva et al., 2004), Uruguay (Antunez et al., 2005), Austria (Berenyi et al., 2006), New Zealand (Todd et al., 2007), Hungary (Forgach et al., 2008), Denmark (Nielsen et al., 2008), Brazil (Teixeira et al., 2008), Spain (unpublished data) and Belgium (unpublished data).

Among the many viruses able to infect honey bees, some have been studied by phylogenetic analysis, including Acute bee paralysis virus (ABPV) (Bakonyi et al., 2002), Sacbrood virus (SBV) (Grabensteiner et al., 2001), Kashmir bee virus (KBV) (Hung et al., 2000), Deformed wing virus (DWV) (Berenyi et al., 2007) and more recently, Israeli acute paralysis virus (IAPV) (Blanchard et al., 2008b; Palacios et al., 2008). While the phylogenetic analysis of SBV and ABPV revealed clustering of the strains according to their geographic origins (Bakonyi et al., 2002; Grabensteiner et al., 2001), the phylogenetic analysis of DWV revealed a monophyletic cluster, despite the various geographic origins of the isolates (Berenyi et al., 2007). The preliminary results on the phylogenetic analysis of IAPV also seem to reveal distinct lineages according to their geographic origins (Blanchard et al., 2008b; Palacios et al., 2008). 
81 Up to date, no study on the genetic diversity of CBPV could be carried out, because of the unavailability of complete nucleotide sequence of CBPV. Recently, we have reported genomic variability between partial sequences of CBPV from different bee samples that led us to develop improved molecular diagnostic methods and quantitative assays (Blanchard et al., $2007,2008 a)$. By using these assays, $40 \%$ of the CBPV isolates that were not detected with the first CBPV RT-PCR test published by our laboratory (Ribière et al., 2002) were successfully detected.

The aim of this study was to assess the genetic relationship among CBPV isolates from various geographic origins. We have chosen to perform the phylogenetic analysis on the Orf3 of CBPV RNA1, reported as the only amino acid sequence sharing significant similarities with the conserved sequence domains of the RNA-dependent RNA polymerase (RdRp) of singlestranded RNA viruses (Olivier et al., 2008). Moreover, Baker and Schroeder (2008) have recently demonstrated the possibility of using the $\mathrm{RdRp}$ as a taxonomic marker for the classification of Picorna-like viruses infecting honey bees. To complete our study, we also performed a phylogenetic analysis on the Orf3 of CBPV RNA2, coding for a predicted structural protein (pSP), as suggested by Olivier et al, (2008).

Samples of adult worker bees were collected from nine countries (Austria, Belgium, Denmark, France, Hungary, Poland, Spain, Switzerland, Uruguay). The samples were collected between 2003 and 2007, from honey bee colonies presenting symptoms of chronic paralysis or abnormal mortalities, except for the Swiss samples and an Austrian sample, where no specific symptoms were identified. Samples tested CBPV-positive, either by the AGID test (Agarose Gel ImmunoDiffusion) (Ribière et al., 2000), or by the RT-PCR test (Ribière et al., 2002) were sent to the bee pathology unit (French Food Safety Agency, Sophia Antipolis, France) for phylogenetic analysis. A total of 101 bee samples were analysed. Sample preparation, RNA extraction and cDNA synthesis were performed as described previously (Blanchard et al., 2007; Ribière et al., 2002). Bee samples were first analysed using the newly developed RT-PCR CBPV test (Blanchard et al., 2008a), completed by the recently upgraded real-time RT-PCR test (Blanchard et al., 2007; Celle et al., 2008). cDNAs of each CBPV positive sample were subjected to supplementary PCRs, allowing to amplify the entire RdRp and the predicted structural protein of CBPV. Sixty-four out of the 101 investigated bee 
111 samples from the different countries were found CBPV positive with high viral load (over $10^{10}$

112 CBPV copies per bee), enabling to amplify the entire RdRp and the pSP.

113 Three different primer pairs were designed by Primer3 Output for the amplification of 114 overlapping fragments which cover the entire RdRp of CBPV (Table 1), based on the 115 sequence of CBPV RNA1 (GenBank accession no. EU122229) described by Olivier et al. 116 (2008). Amplifications were carried out in a total reaction volume of $50 \mu$ l using the Platinum ${ }^{\circledR}$ 117 Pfx DNA Polymerase (Invitrogen). This polymerase has a proofreading 3'-5' exonuclease 118 activity, and therefore provides higher fidelity. The final PCR reaction contained 2X Platinum ${ }^{\circledR}$ 119 Pfx Amplification Buffer, $1 \mathrm{mM}$ of $\mathrm{MgSO}_{4}, 0.3 \mathrm{mM}$ of dNTPs mix PCR grade, $0.3 \mu \mathrm{M}$ of each 120 primer, $2.5 \mathrm{U}$ of Platinum ${ }^{\circledR}$ Pfx DNA Polymerase and $5 \mu \mathrm{l}$ of cDNA. The thermal cycling 121 conditions were $5 \mathrm{~min}$ at $94^{\circ} \mathrm{C}$ (denaturing of the template and activation of the enzyme), 122 followed by 35 cycles consisting of denaturing at $94^{\circ} \mathrm{C}$ for $15 \mathrm{~s}$, annealing at $55^{\circ} \mathrm{C}$ for $30 \mathrm{~s}$ 123 and extension at $68^{\circ} \mathrm{C}$ for $30 \mathrm{~s}$ to 2 min (depending on the primer pair), completed by a final 124 extension at $68^{\circ} \mathrm{C}$ for $10 \mathrm{~min}$. The PCR products were then electrophoresed in $1 \%$ agarose 125 gel in TAE buffer, stained with ethidium bromide, and visualised under UV light. The PCR 126 products were then purified using the Qiaquick PCR purification kit (Qiagen) and sequenced 127 in both orientations by using primers described above (Millegen, France). The complete 128 genomic nucleotide sequence of the RdRp of different CBPV isolates (1947bp) was 129 determined by overlapping the three sequences using the Seqman ${ }^{\mathrm{TM}}$ II program of the 130 DNASTAR software package (Lasergene). A primer pair was designed, covering the entire 131 Orf3 (543bp), coding for a predicted structural protein (pSP) (Table 1), based on the 132 sequence of CBPV RNA2 (GenBank accession no. EU122230) described by Olivier et al. 133 (2008). Amplification, PCR product purification, sequencing and nucleotide sequence 134 determination were carried out as described for the RdRp gene.

135 Preliminary comparison of the sequences from isolates from the same geographical origin 136 revealed that most frequently they shared near $100 \%$ identity. The analysis was thus 137 restricted to the divergent sequences ( 5 from France and 17 from different countries, Table 138 2). The nucleotide sequences of the RdRp and the pSP from the 22 new isolates were 139 submitted to the GenBank database under accession numbers FJ345306 to FJ345349. The 140 nucleotide sequence of RdRp and pSP of CBPV reference isolates $A$ and $B$, were determined 
141 respectively from RNA1 (GenBank accession nos. EU122229 and EU122231) and RNA2

142 sequences (GenBank accession nos. EU122230 and EU122232), described previously by

143 Olivier et al. (2008). In this study, CBPV reference isolates A and B were respectively named

$144 \quad$ Fr 1 and Fr 2.

145 Nucleotide sequences of RdRp and predicted structural protein were aligned by using the 146 MegAlign $^{\text {TM }}$ program of the DNASTAR software package (Lasergene) and the CLUSTAL_X 147 program (Thompson et al., 1997). The final alignment was checked by visual inspection. 148 Phylogenetic analysis was performed by using the neighbour-joining (NJ), maximum 149 likelihood (ML) and maximum parsimony (MP) methods implemented in the PHYLOWIN 150 program (Galtier et al., 1996), and by using the NJ and MP methods implemented in the 151 Molecular Evolutionary Genetics Analysis (MEGA) program version 3.1 (Kumar et al., 2004). 152 All methods gave similar profiles. Results using the MEGA software are shown. Branches 153 were condensed when bootstrap values were less than $70 \%$.

154 The analysis of the sequence pair distances using the Clustal W method revealed $0.3-9.6 \%$ 155 divergence between the $24 \mathrm{RdRp}$ nucleotide sequences and 0.2-4.6\% divergence between 156 the $24 \mathrm{RdRp}$ amino acid sequences. The phylogenetic relationship among the $24 \mathrm{CBPV}$ 157 RdRp sequences was assessed and revealed four main clusters, supported by high bootstrap 158 values (Figure 1) using NJ, ML and MP methods of analysis. Lineage A contained most of 159 French isolates (5/7) and the isolates from Spain and Belgium. Lineage B contained a French 160 isolate, two Swiss isolates and all the Polish, Austrian, Danish and Hungarian isolates. 161 Lineage $C$ contained two Uruguayan isolates and lineage $D$ contained 3 isolates obtained 162 from different countries (France, Switzerland and Uruguay). Since isolates from Uruguay, 163 Switzerland and France were present in several clusters, no clear geographical segregation 164 was observed. However, lineage A mainly contains isolates from South and Western Europe, 165 compared to lineage B clustering isolates from North and Eastern Europe, while lineage C 166 contains isolates from South America. The clustering of a French, a Swiss and an Uruguayan 167 isolates (Lineage D) remains unexplained and raises the question of the possible role of 168 commercial exchange of honey bees. However, the presence of French isolates in three of 169 four major lineages (5 in lineage A, 1 in lineage B and 1 in lineage D) could actually results 170 from the over representation of isolates from France. Studying more isolates originating from 
171 a broader range of countries could help to definitively identify geographical trends. In this 172 study, no correlation between sequence variation and occurrence of clinical symptoms was 173 observed. The branching of the phylogenetic tree did not enable the segregation of CBPV 174 isolates from symptomatic (83\%) and asymptomatic bee colonies (17\%).

175 The phylogenetic relationship among the 24 CBPV pSP sequences revealed a similar profile 176 to that obtained with the RdRp sequences (Figure 2), except for an Uruguayan isolate (Ur 3).

177 The pSP of this isolate clustered in lineage $B$, compared to the RdRp of this isolate, which 178 clustered in lineage $C$. Moreover, lineage $C$ and $D$ were clustered together. While the 179 alignment of the $24 \mathrm{pSP}$ nucleotide sequence revealed $0-6.6 \%$ divergence, the alignment of 180 the 24 pSP amino acid sequences showed a very low degree of divergence $(0-2.3 \%$ 181 corresponding to only 2 amino acids), unexpectedly suggesting a highly conserved protein. 182 Due to its low variability, pSP sequence seems not to be indicated for phylogenetic study, 183 while RdRp sequences are more discriminating. Whereas it is very likely that the Orf3 of 184 CBPV RNA1 encodes the viral RdRp (Olivier et al., 2008), it is necessary to further 185 characterize the proteins encoded by the different ORFs of the CBPV genome (work in 186 progress in our laboratory).

187 In conclusion, this study underlines the presence of chronic paralysis outbreaks in several 188 countries and points to the need to assess the impact of this disease in colony weakness 189 worldwide. Further investigations on CBPV isolates from a broader origin are necessary to 190 confirm their geographical distribution, to assess the global distribution of this virus and to 191 further investigate the CBPV role in disease outbreaks.

\section{Acknowledgements}

194 This work was supported by the French Ministère de l'Agriculture et de l'Alimentation and with 195 funds from the "Fonds Européens d'Orientation et de Garantie Agricole" (FEOGA), in 196 accordance with the French programme for the improvement of the production and 197 commercialisation of beekeeping products. The authors are grateful to the collaborators and 198 beekeepers for having kindly provided bee samples. The help of Ms. Cristina Gastaldi in 199 improving the English of the manuscript is gratefully acknowledged. 


\section{References}

202 Allen, M. \& Ball, B. V. 1996. The incidence and world distribution of honey bee viruses. Bee 203 World 77, 141-162.

204 Antunez, K., D', A. B., Corbella, E. \& Zunino, P. 2005. Detection of chronic bee paralysis virus 205 and acute bee paralysis virus in Uruguayan honeybees. J. Invertebr. Pathol. 90, 69-72.

206 Bailey, L., Ball, B. V. \& Perry, J. N. 1981. The prevalence of viruses of honey bees in Britain. 207 Ann. Appl. Biol. 97, 109-118.

208 Bailey, L., Ball, B. V. \& Perry, J. N. 1983. Honeybee paralysis: its natural spread and its 209 diminished incidence in England and Wales. J. Apic. Res. 22, 191-195.

210 Baker, A. C. \& Schroeder, D. C. 2008. The use of RNA-dependent RNA polymerase for the 211 taxonomic assignment of Picorna-like viruses (order Picornavirales) infecting Apis mellifera L. 212 populations. Virol. J. 5, 10.

213 Bakonyi, T., Grabensteiner, E., Kolodziejek, J., Rusvai, M., Topolska, G., Ritter, W. \& 214 Nowotny, N. 2002. Phylogenetic analysis of acute bee paralysis virus strains. Appl. Environ. 215 Microbiol. 68, 6446-6450.

216 Ball, B. V. \& Bailey, L. 1997. Viruses. In: Morse, R.A. Flottum, K. (Eds), Honey Bee Pests, 217 Predators, \& Diseases, third ed A.I. Root Company, Medina, pp. 11-32..

218 Berenyi, O., Bakonyi, T., Derakhshifar, I., Koeglberger, H. \& Nowotny, N. 2006. Occurrence of 219 six honeybee viruses in diseased austrian apiaries. Appl. Environ. Microbiol. 72, 2414-2420.

220 Berenyi, O., Bakonyi, T., Derakhshifar, I., Koeglberger, H., Topolska, G., Ritter, W.,

221 Pechhacker, H. \& Nowotny, N. 2007. Phylogenetic analysis of deformed wing virus genotypes

222 from diverse geographic origins indicates recent global distribution of the virus. Appl. Environ.

223 Microbiol. 73, 3605-3611.

224 Blanchard, P., Ribiere, M., Celle, O., Lallemand, P., Schurr, F., Olivier, V., Iscache, A. L. \&

225 Faucon, J. P. 2007. Evaluation of a real-time two-step RT-PCR assay for quantitation of

226 Chronic bee paralysis virus (CBPV) genome in experimentally-infected bee tissues and in life

227 stages of a symptomatic colony. J. Virol. Methods 141, 7-13.

228 Blanchard, P., Olivier, V., Iscache, A. L., Celle, O., Schurr, F., Lallemand, P. \& Ribiere, M. 229 2008a. Improvement of RT-PCR detection of chronic bee paralysis virus (CBPV) required by 230 the description of genomic variability in French CBPV isolates. J. Invertebr. Pathol. 97, 182231185.

Blanchard, P., Schurr, F., Celle, O., Cougoule, N., Drajnudel, P., Thiery, R., Faucon, J. P. \& Ribiere, M. 2008b. First detection of Israeli acute paralysis virus (IAPV) in France, a dicistrovirus affecting honeybees (Apis mellifera). J. Invertebr. Pathol. 99, 348-350.

Celle, O., Blanchard, P., Olivier, V., Schurr, F., Cougoule, N., Faucon, J. P. \& Ribiere, M. 237 in various hosts and possible ways of spread. Virus Res. 133, 280-284.

238 Forgach, P., Bakonyi, T., Tapaszti, Z., Nowotny, N. \& Rusvai, M. 2008. Prevalence of pathogenic bee viruses in Hungarian apiaries: situation before joining the European Union. J. Invertebr. Pathol. 98, 235-238.

241 Galtier, N., Gouy, M. \& Gautier, C. 1996. SEAVIEW and PHYLO_WIN: two graphic tools for 
Grabensteiner, E., Ritter, W., Carter, M. J., Davison, S., Pechhacker, H., Kolodziejek, J., Boecking, O., Derakhshifar, I., Moosbeckhofer, R., Licek, E. \& Nowotny, N. 2001. Sacbrood virus of the honeybee (Apis mellifera): rapid identification and phylogenetic analysis using reverse transcription-PCR. Clin. Diagn. Lab. Immunol. 8, 93-104.

Hung, A. C. F., Peng, C. Y. S. \& Shimanuki, H. 2000. Nucleotide sequence variations in Kasmir bee virus isolated from Apis mellifera $L$. and Varroa jacobsoni Oud. Apidologie 31, 1723.

Kumar, S., Tamura, K., Nei, M., 2004. MEGA3: integrated software for Molecular Evolutionary

Mayo, M.A., Christian, P.D., Hillman, B.I., Brunt, A.A., Desselberger, U., 2005. Unassigned Viruses. In: Fauquet, C.M., Mayo, M.A., Maniloff, J., Desselberger, U., Ball, L.A. (Eds.), Virus Taxonomy. The Eigth Report of the International Committee on Taxonomy of Viruses. Elsevier, San Diego, 1131-1144.

Nielsen, S. L., Nicolaisen, M. \& Kryger, P. 2008. Incidence of acute bee paralysis virus, black queen cell virus, chronic bee paralysis virus, deformed wing virus, Kashmir bee virus and sacbrood virus in honey bees (Apis mellifera) in Denmark. Apidologie 39, 310-314.

Olivier, V., Blanchard, P., Chaouch, S., Lallemand, P., Schurr, F., Celle, O., Dubois, E., Tordo, N., Thiéry, R., Houlgatte, R. \& Ribière, M. 2008. Molecular characterisation and phylogenetic analysis of Chronic bee paralysis virus, a honey bee virus. Virus Res. 132, 5968.

Palacios, G., Hui, J., Quan, P. L., Kalkstein, A., Honkavuori, K. S., Bussetti, A. V., Conlan, S., Evans, J., Chen, Y. P., Vanengelsdorp, D., Efrat, H., Pettis, J., Cox-Foster, D., Holmes, E. C., Briese, T. \& Lipkin, W. I. 2008. Genetic analysis of Israel acute paralysis virus: distinct clusters are circulating in the United States. J. Virol. 82, 6209-6217.

Ribière, M., Ball, B. \& Aubert, M. 2008. Natural history and geographical distribution of honey bee viruses. In: Aubert, M., Ball, B., Fries, I., Moritz, R., Milani, N., Bernardinelli, I.(Eds), Virology and the Honey Bee, European Commission, Bruxelles, pp. 15-84..

Ribière, M., Faucon, J. P. \& Pépin, M. 2000. Detection of chronic bee paralysis virus infection: application to a field survey. Apidologie 31, 567-577.

Ribière, M., Triboulot, C., Mathieu, L., Aurières, C., Faucon, J. P. \& Pépin, M. 2002. Molecular diagnosis of chronic bee paralysis virus infection. Apidologie 33, 339-351.

Teixeira, E. W., Chen, Y., Message, D., Pettis, J. \& Evans, J. D. 2008. Virus infections in Brazilian honey bees. J. Invertebr. Pathol. 99, 117-119.

Tentcheva, D., Gauthier, L., Zappulla, N., Dainat, B., Cousserans, F., Colin, M. E., Bergoin, M. 2004. Prevalence and seasonal variations of six bee viruses in Apis mellifera $L$. and Varroa destructor Mite Populations in France. Appl. Environ. Microbiol. 70, 7185-7191.

Thompson, J. D., Gibson, T. J., Plewniak, F., Jeanmougin, F. \& Higgins, D. G. 1997. The CLUSTAL_X windows interface: flexible strategies for multiple sequence alignment aided by quality analysis tools. Nucleic Acids Res. 25, 4876-4882.

Todd, J. H., de Miranda, J. R. \& Ball, B. V. 2007. Incidence and molecular characterization of viruses found in dying New Zealand honey bee (Apis mellifera) colonies infested with Varroa destructor. Apidologie 38, 354-367. 
289 Table 1

290 Oligonucleotide primers used for the amplification of the RNA-dependent RNA polymerase 291 (RdRp, position 1643-3589 on RNA1) and for the amplification of the predicted structural 292 protein (pSP, position 303-845 on RNA2).

294 Table 2

295 Origin of the studied CBPV isolates used for the phylogenetic analysis: isolate reference, year 296 of sampling, presence of CBPV symptoms, country of origin, identification of sequence and 297 GenBank accession number.

299 Figure 1

300 Phylogenetic tree constructed using the neighbour-joining ( $\mathrm{NJ}$ ) method with Kimura 301 parameters, included in the MEGA version 3.1 program (Kumar et al., 2004), on the alignment 302 of the $1947 \mathrm{bp}$ of RdRp sequence of $24 \mathrm{CBPV}$ isolates. The number of each node represents 303 the bootstrap values as the result of 1000 replicates. Branches were condensed when 304 bootstrap values were less than $70 \%$.

305

306 Figure 2

307 Phylogenetic tree constructed using the neighbour-joining $(\mathrm{NJ})$ method with Kimura 308 parameters, included in the MEGA version 3.1 program (Kumar et al., 2004), on the alignment 309 of the $543 \mathrm{bp}$ of predicted structural protein sequence of $24 \mathrm{CBPV}$ isolates. The number of 310 each node represents the bootstrap values as the result of 1000 replicates. Branches were 311 condensed when bootstrap values were less than $70 \%$. 
313

314

315

Table 1.

316

\begin{tabular}{|c|c|c|c|c|}
\hline Target & Primer Name & Sequence $\left(5^{\prime}-3^{\prime}\right)$ & Position & $\begin{array}{l}\text { PCR product } \\
\text { size (bp) }\end{array}$ \\
\hline \multirow{6}{*}{ CBPV RNA 1 RdRp } & CBPV A1 & TGAGGCTTGCTTCTGACAAA & $1589-1608^{*}$ & \multirow{2}{*}{902} \\
\hline & CBPV A2 & ACTACTAGAAACTCGTCGCTTCG & $2490-2468^{*}$ & \\
\hline & CBPV A3 & TCAGACACCGAATCTGATTATTG & 1921-1933* & \multirow{2}{*}{1525} \\
\hline & CBPV A4 & CCGGAGACAAAGGTCATCAT & $3445-3426^{*}$ & \\
\hline & CBPV A5 & GGCCCATCATGCAGAAGTAT & $3264-3283^{*}$ & \multirow{2}{*}{404} \\
\hline & CBPV A6 & ACCAGTGCCTGACGGACTTA & $3667-3646^{*}$ & \\
\hline \multirow{2}{*}{ CBPV RNA 2 pSP } & CBPV A7 & ACTCCCGTCGTTGTGTTCTC & $109-128^{\circ}$ & \multirow{2}{*}{895} \\
\hline & CBPV A8 & GGCGATTGGTATTTGTTTGG & $1003-984^{\circ}$ & \\
\hline
\end{tabular}

317

318 * Nucleotide positions refer to the CBPV RNA1 sequence (EU122229) described by Olivier et 319 al., (2008).

$320{ }^{\circ}$ Nucleotide positions refer to the CBPV RNA2 sequence (EU122230) described by Olivier et 321 al., (2008).

322 


\begin{tabular}{|c|c|c|c|c|c|}
\hline Isolate ${ }^{1} /$ Year & Country & Symptoms ${ }^{2}$ & Identification & $\begin{array}{c}\text { GenBank } \\
\text { accession no. } \\
\text { CBPV RdRp }\end{array}$ & $\begin{array}{c}\text { GenBank } \\
\text { accession no } \\
\text { CBPV pSP } \\
\end{array}$ \\
\hline$A^{*} / 2004$ & France & Yes & Fr 1 & EU122229 & EU122230 \\
\hline$B^{*} / 2005$ & France & Yes & Fr 2 & EU122231 & EU122232 \\
\hline $198 / 2007$ & France & Yes & $\operatorname{Fr} 6$ & FJ345313 & FJ345334 \\
\hline $596 / 2007$ & France & Yes & $\operatorname{Fr} 7$ & FJ345314 & FJ345335 \\
\hline $351 / 2007$ & France & Yes & Fr 8 & FJ345315 & FJ345336 \\
\hline $363 / 2007$ & France & Yes & Fr 9 & FJ345316 & FJ345337 \\
\hline 274 / 2007 & France & Yes & Fr 10 & FJ345312 & FJ345338 \\
\hline 8-C / 2006 & Uruguay & Yes & Ur 1 & FJ345325 & FJ345347 \\
\hline $6-M / 2006$ & Uruguay & Yes & Ur 2 & FJ345326 & FJ345348 \\
\hline 13-F / 2006 & Uruguay & Yes & Ur 3 & FJ345327 & FJ345349 \\
\hline R1-C6 / 2004 & Switzerland & No & Sw 1 & FJ345322 & FJ345344 \\
\hline R2-C102 / 2004 & Switzerland & No & Sw 2 & FJ345323 & FJ345345 \\
\hline R3-C10 / 2004 & Switzerland & No & Sw 3 & FJ345324 & FJ345346 \\
\hline BE 104 / 2003 & Austria & Yes & Au 1 & FJ345306 & FJ345328 \\
\hline BE 78 / 2006 & Austria & No & Au 5 & FJ345308 & FJ345329 \\
\hline AT 34 / 2004 & Austria & Yes & Au 19 & $\overline{F J 345307}$ & FJ345330 \\
\hline H4 300 / 2005 & Hungary & Yes & $\mathrm{Hu} 15$ & $\overline{F J 345317}$ & FJ345339 \\
\hline $1 \mathrm{M} / 2006$ & Poland & Yes & Po 1 & FJ345318 & FJ345340 \\
\hline $3 \mathrm{NZ} / 2006$ & Poland & Yes & Po 3 & FJ345319 & FJ345341 \\
\hline $4 \mathrm{RZ} / 2006$ & Poland & Yes & Po 4 & FJ345320 & FJ345342 \\
\hline $1 \mathrm{~W} / 2006$ & Poland & Yes & Po 6 & FJ345321 & FJ345343 \\
\hline$L-4 / 2007$ & Denmark & Yes & De 4 & FJ345310 & FJ345332 \\
\hline B4 V / 2006 & Spain & Yes & Sp 1 & $\overline{F J 345311}$ & $\overline{F J 345333}$ \\
\hline 23 / 2006 & Belgium & Yes & $\mathrm{Be} 23$ & FJ345309 & FJ345331 \\
\hline
\end{tabular}


340

341

342

343

344

345

346

347

348

349

350

351

352

353

354

355

356

357

358

359

360

Figure 1

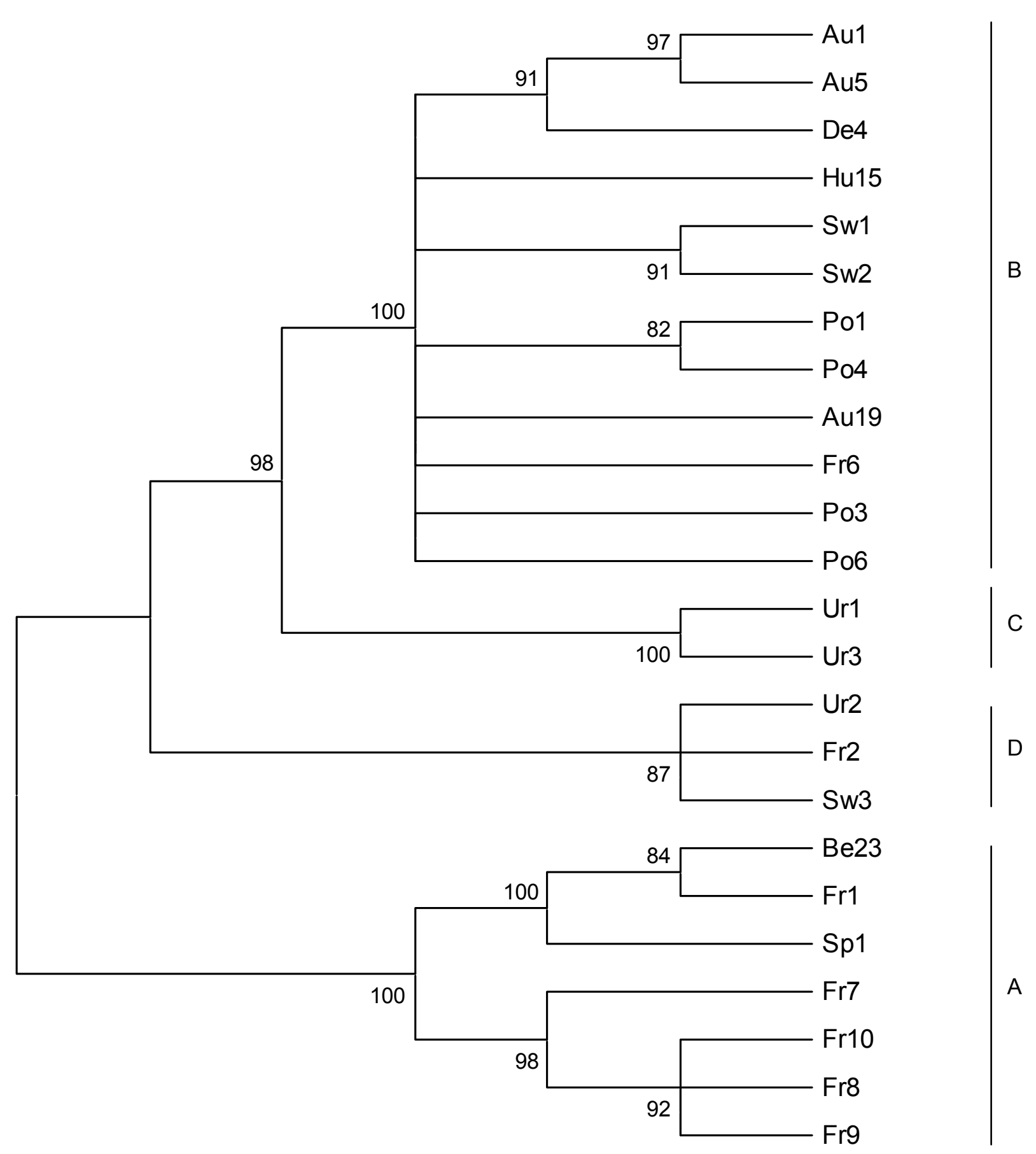


Figure 2

362

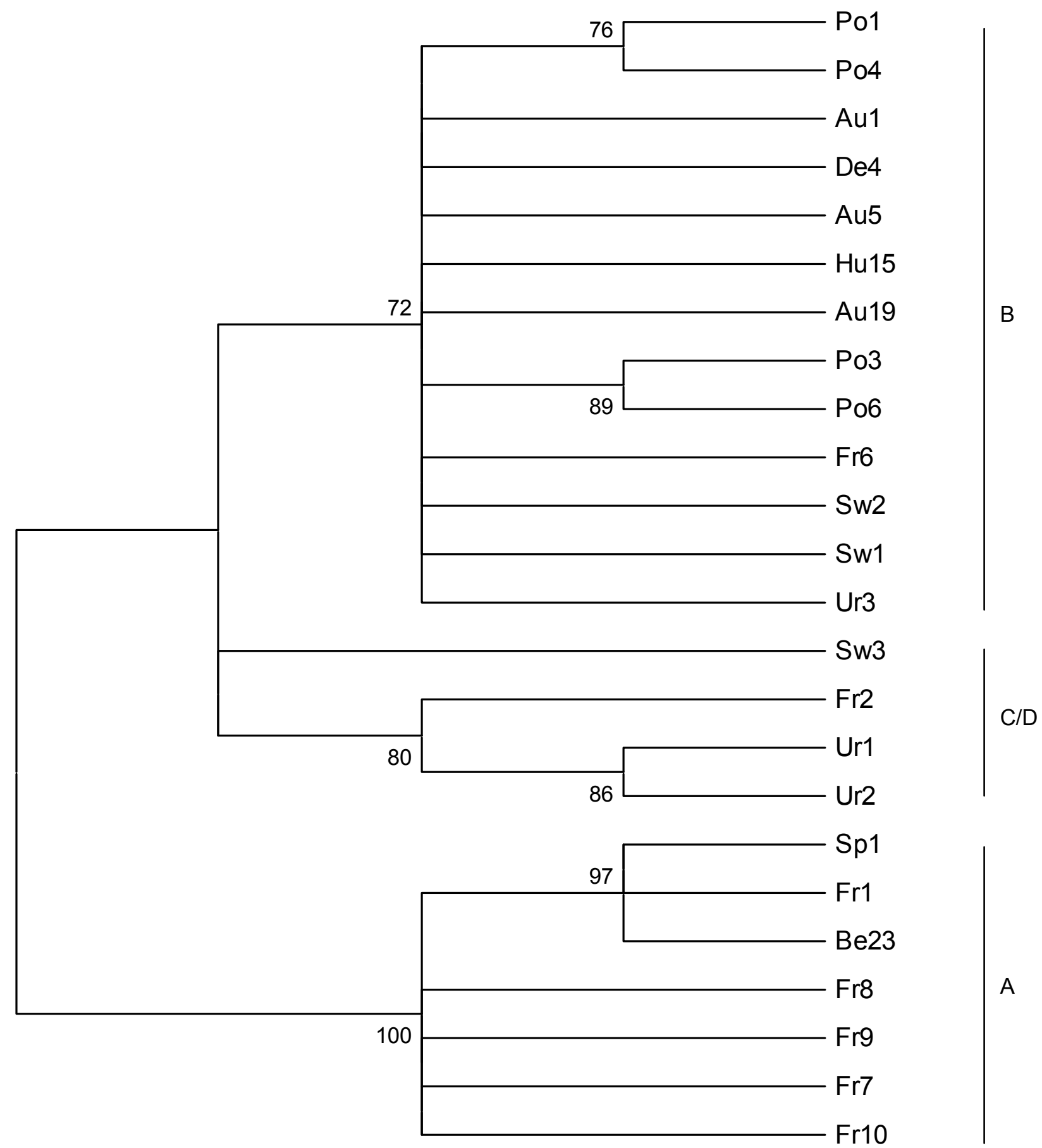

